University of Nebraska - Lincoln

DigitalCommons@University of Nebraska - Lincoln

2006

\title{
A Minimum-Impact Method for Measuring Corrosion Rate of Steel-Hulled Shipwrecks in Seawater
}

\author{
Matthew A. Russell \\ National Park Service, Submerged Resources Center \\ David Conlin \\ National Park Service, Submerged Resources Center \\ Larry E. Murphy \\ National Park Service, Submerged Resources Center \\ Donald L. Johnson \\ University of Nebraska-Lincoln, johnsondonl@aol.com \\ Brent Wilson \\ University of Nebraska-Lincoln, bwilson3@unl.edu
}

See next page for additional authors

Follow this and additional works at: https://digitalcommons.unl.edu/mechengfacpub

Part of the Mechanical Engineering Commons

Russell, Matthew A.; Conlin, David; Murphy, Larry E.; Johnson, Donald L.; Wilson, Brent; and Carr, James, "A Minimum-Impact Method for Measuring Corrosion Rate of Steel-Hulled Shipwrecks in Seawater" (2006). Mechanical \& Materials Engineering Faculty Publications. 9.

https://digitalcommons.unl.edu/mechengfacpub/9

This Article is brought to you for free and open access by the Mechanical \& Materials Engineering, Department of at DigitalCommons@University of Nebraska - Lincoln. It has been accepted for inclusion in Mechanical \& Materials Engineering Faculty Publications by an authorized administrator of DigitalCommons@University of Nebraska Lincoln. 


\section{Authors}

Matthew A. Russell, David Conlin, Larry E. Murphy, Donald L. Johnson, Brent Wilson, and James Carr 


\title{
A Minimum-Impact Method for Measuring Corrosion Rate of Steel-Hulled Shipwrecks in Seawater
}

\author{
Matthew A. Russell, David L. Conlin and Larry E. Murphy \\ National Park Service, Submerged Resources Center, 2968 Rodeo Park Drive West, Santa Fe, NM 87505, USA \\ Donald L. Johnson and Brent M. Wilson \\ Metallurgical Engineering Group, University of Nebraska-Lincoln, 104 N. Walter Scott Engineering Center, Lincoln, \\ NE 68588, USA
}

James D. Carr

Department of Chemistry, University of Nebraska-Lincoln, 635 HaH, Lincoln, NE 68588, USA

Current research on USS Arizona is focused on a minimum-impact technique for calculating corrosion rate of the battleship's steel hull by analysing physical and chemical properties of marine encrustation covering the exposed hull. An equation is derived that allows concretion thickness, density, and total iron content to be used to calculate corrosion rate of steel hull plate.

(C) 2006 The Authors

Key words: USS Arizona, steel corrosion, battleship, concretion, marine encrustation.

$\mathbf{T}$ The National Park Service's (NPS) Submerged Resources Center (SRC) and USS Arizona Memorial (USAR) are collaborating with the University of NebraskaLincoln (UNL) on research directed at understanding the nature and rate of natural processes affecting the deterioration of USS Arizona in Pearl Harbour, Hawaii (Fig. 1). The Pennsylvaniaclass battleship USS Arizona, completed in 1916, was sunk in Pearl Harbour on 7 December 1941 during the Japanese attack on the US Navy's Pacific Fleet. In the first 15 minutes of the attack, Arizona endured hits from several bombs, was strafed, and then at about 08.10 the battleship suffered a mortal blow. A Japanese Nakajima B5N2 'Kate' horizontal bomber dropped a single 1760-pound projectile that struck near Turret No. 2, penetrating deep into the battleship's interior before exploding and sympathetically detonating the forward magazine. When the forward magazine exploded most of the battleship's forward half was destroyed below the upper deck, including the forward oil bunkers. The ship sank in minutes, but the explosion ignited fires that raged for $2 \frac{1}{2}$ days. A total of 1177 sailors and marines aboard Arizona were killed, and nearly 1000 men are still entombed within the ship. USS Arizona's loss remains the largest single-ship loss of life in US naval history.

The USS Arizona Preservation Project is multiyear, interdisciplinary and cumulative, with each element contributing to provide the basic research required to make informed management decisions for the battleship's long-term preservation. This project builds upon prior documentation and research conducted by SRC during the 1980s (Lenihan, 1989) and follows the minimumimpact approach advocated by the NPS (Murphy and Russell, 1997). The primary project focus is acquiring requisite data to understand the complex corrosion and deterioration processes affecting Arizona's hull, both internally and externally, and modelling and predicting the nature and rate of structural changes (Russell and Murphy, 2003; Russell and Murphy, 2004; Russell et al., 2004).

An important aspect of this project is accurately to determine remaining hull thickness for inclusion in a Finite Element Analysis (FEA) being conducted by the National Institute of 


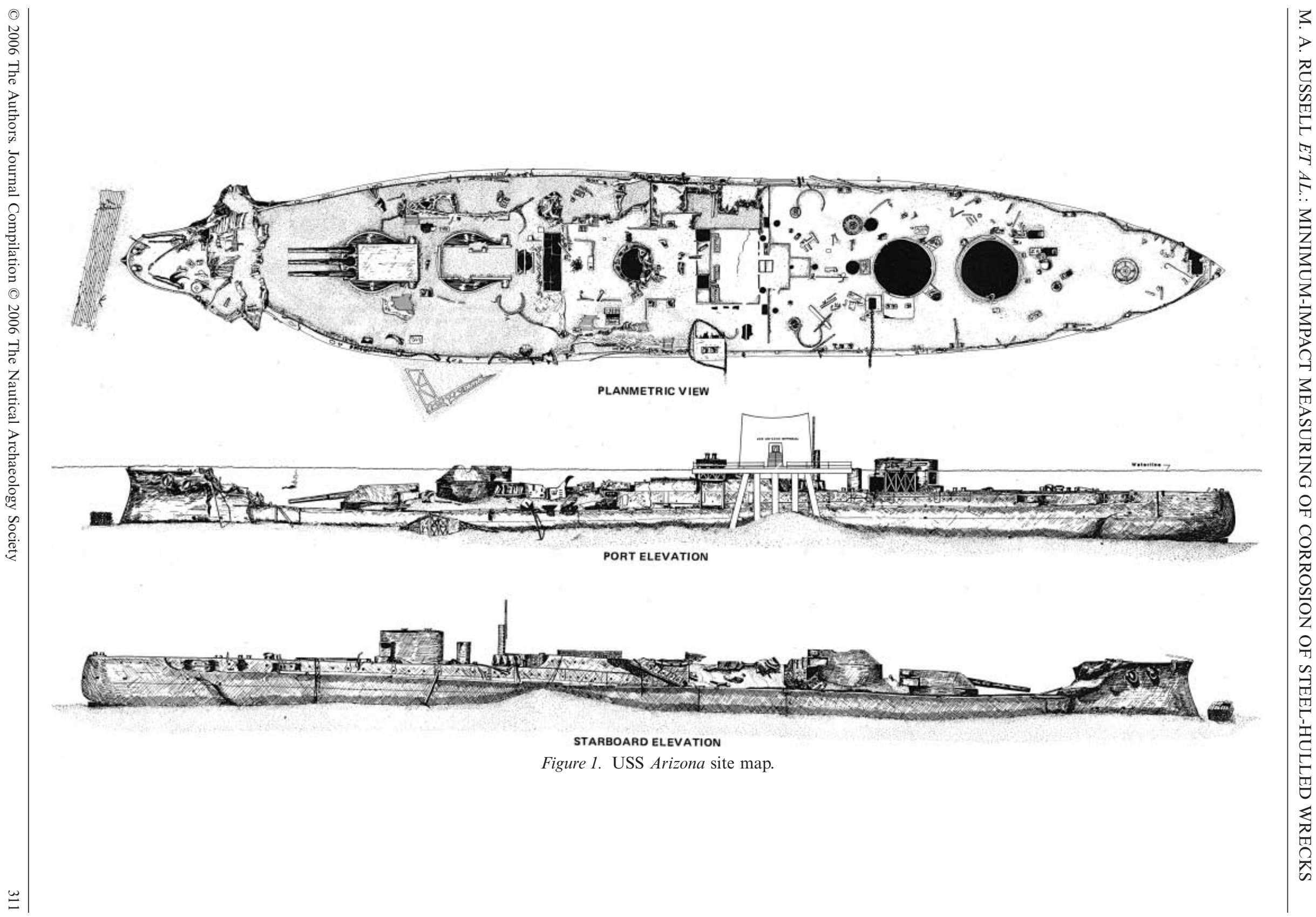




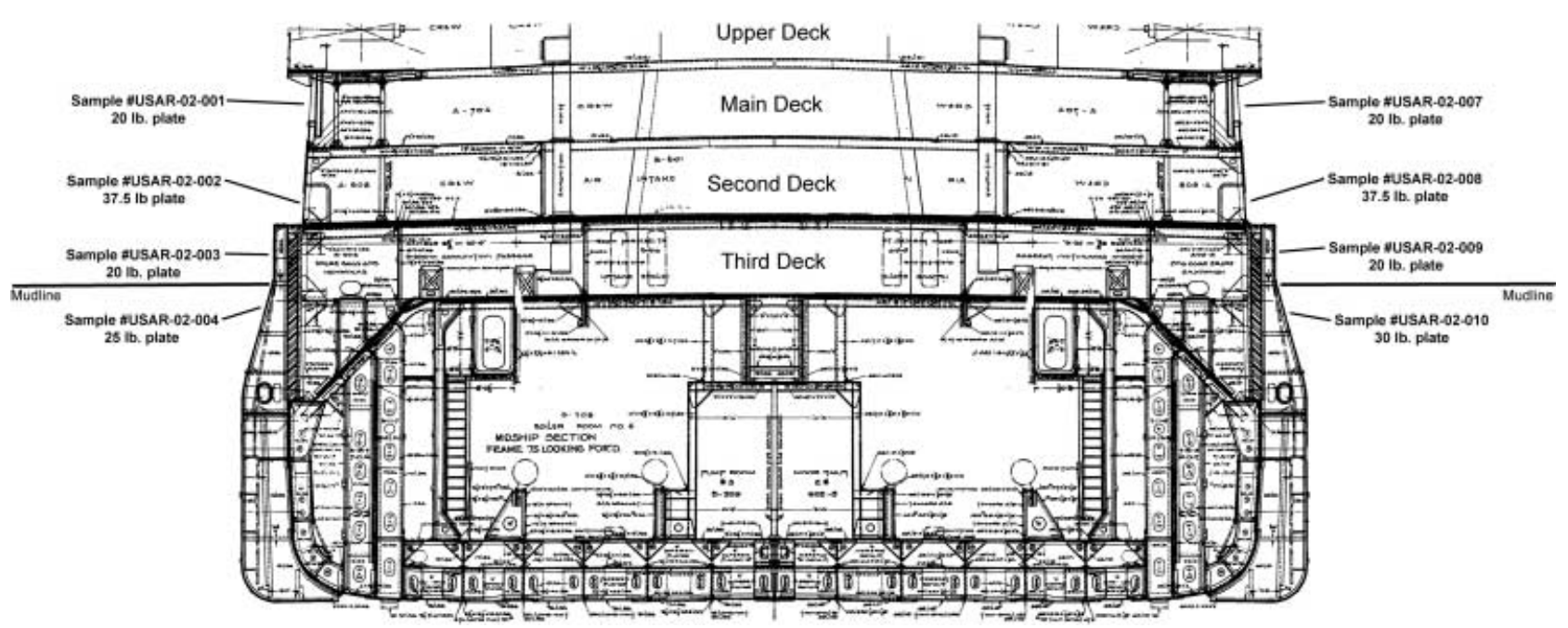

Figure 2. Cross-section of USS Arizona's midship at Frame 75 showing hull coupon locations.

Standards and Technology (NIST) in Gaithersburg, MD. The FEA is designed to model Arizona's structural deterioration and eventual collapseinformation critical for developing a sound, scientifically-based management plan and for determining when, or if, intervening in the vessel's natural deterioration should be considered. A key first-step in this process is determining the remaining thicknesses (and by extension structural strength) of surviving hull components. This paper will outline a minimum-impact method for deriving the corrosion rate of Arizona's steel hull by analysing physical and chemical properties of the marine encrustation that covers exposed steel surfaces.

\section{Background}

During the marine corrosion process, unlike cast or wrought iron, the microstructure of steel (USS Arizona is low-carbon steel, see Johnson et al., 2000; Makinson et al., 2002) does not result in a remnant layer that preserves the original surface to allow direct measurement of metal lost over time. Because of this, we were unable to use techniques to determine iron corrosion rates pioneered in Australia and later applied elsewhere (e.g. MacLeod, 1987; McCarthy, 1988; MacLeod, 1995; Gregory, 1999). For steel vessels, the most accurate measure of metal loss is to determine actual steel thickness and subtract this value from original thickness specified on ship's plans. Once total metal-loss over a given time is known, average corrosion rate can be calculated. Measuring actual steel thickness can be accomplished by direct measurement or by using ultrasonic thickness instruments; however, each of these has serious limitations as discussed below. Because Arizona is both a war-grave and has international significance, as an alternative, we are experimenting with a minimum-impact method to determine corrosion rate of the steel hull using density, thickness and total iron content of the concretion-for our purposes, this is the best combination of minimum impact and reliability.

\section{Direct-measurement technique}

As an initial control for this research, $10-\mathrm{cm}$ (4-in) diameter hull samples ('coupons'), including intact exterior and interior concretion, were removed using a hydraulic-powered hole saw with a task-specific bit designed to retain the coupon plus interior and exterior concretion. Eight coupons were removed from external, vertical hull locations on both port and starboard sides (Figs 2 and 3). On each side of the ship, one sample was taken from the upper-deck level near the water line; from the second-deck level above the torpedo blister; from the third-deck level in the torpedo blister; and from the first platform level in the torpedo blister below the mud-line. Immediately after removal, each location was plugged using a standard plumber's pipe plug and sealed with marine epoxy to prevent formation of localised corrosion cells and minimize exchange of interior and exterior water.

UNL researchers used metallographic and optical methods to measure recovered coupon 


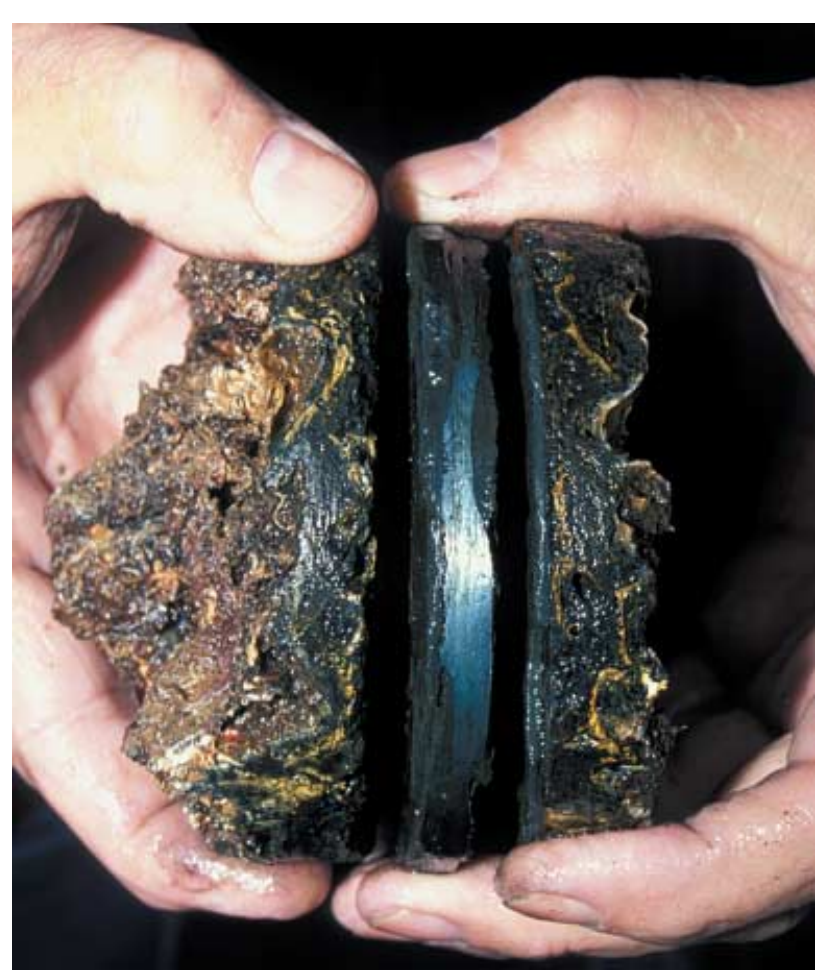

Figure 3. Hull coupon no. USAR-02-001, showing interior and exterior concretion. This sample is from the main deck, outer hull, in water less than $2 \mathrm{~m}$ deep with continuous seawater circulation on both sides, which explains thick concretion on both sides and extensive steel corrosion. (Brett Seymour/NPS)

thickness at Rail Sciences, Inc. in Omaha, Nebraska (Johnson et al., 2003: 74-80). Although there is some unevenness across the surface of each coupon, corrosion was essentially uniform. Researchers measured steel thickness in nine locations on each coupon and averaged the measurements to obtain a thickness for each sample. The original ship plans provided as-built steel thickness in terms of theoretical weight, in pounds per square foot, at each location (Johnson et al., 2003: 82). Standard tables were used to convert theoretical weight to nominal thickness in inches - unfortunately, no thickness tolerances are available.

\section{Data analysis}

With this data in hand, we were able to calculate corrosion rates according to the following:

$$
\text { Metal loss }=\mathrm{T}_{\mathrm{o}}-\mathrm{T}_{\mathrm{a}}
$$

where

$\mathrm{T}_{\mathrm{o}}$ is original thickness

$\mathrm{T}_{\mathrm{a}}$ is actual thickness
We define the corrosion rate, $\left(i_{\text {corr }}\right)$, as the metal loss per unit of time:

$$
i_{\text {corr }}=\frac{\left(T_{o}-T_{a}\right)}{t}
$$

When using English units, we prefer to use a corrosion rate with units of mils per year (mils/yr) where one mil is 1/1000 of an inch; when using the International System of Units (SI), we prefer to use a corrosion rate with units of microns per year $(\mu \mathrm{m} / \mathrm{yr})$ where one micron is $1 / 1000$ of a millimetre. When the original and actual plate thicknesses are defined in either inches or millimetres, the corrosion rate equation becomes:

$$
\mathrm{i}_{\text {corr }}=\frac{(1000)\left(\mathrm{T}_{\mathrm{o}}-\mathrm{T}_{\mathrm{a}}\right)}{\mathrm{t}}
$$

where

$\mathrm{t}$ is the exposure time in years (yr)

When metal loss is defined in inches, equation [3] expresses corrosion rate in mils/yr; when the metal loss is defined in millimetres, equation [3] expresses corrosion rate in $\mu \mathrm{m} / \mathrm{yr}$. This is a simplified expression that assumes a constant corrosion rate. Although we recognize that initial corrosion rates are high and decrease over time as concretion forms, we assume that corrosion rates stabilized fairly quickly (within a matter of years) and that most of Arizona's lifespan under water has been at a uniform corrosion rate.

Results from equation [1] for each coupon are given in Fig. 4 as a function of water-depth, and the results from equation [3] are given in Table 1. Because coupons were collected in 2002, $t=61$ $\mathrm{yr}$ for these calculations. Note that for the two shallowest samples in Table 1 (USAR-02-001

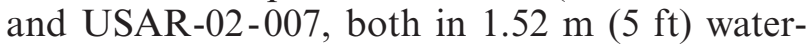
depth), corrosion rate $\left(i_{\text {corr }}\right)$ was halved from the absolute value obtained from the directmeasurement technique. Values were halved because, at those two locations, both the inside and outside of the hull are open to free-circulating seawater causing corrosion and concretion formation on both the interior and exterior sides of the hull, effectively doubling the corrosion rate. On all other samples there was little observable interior corrosion or concretion formation, and internal dissolved oxygen levels measured after coupon removal were at or near zero, indicating the majority of corrosion was taking place on the exterior only. Therefore, to be consistent with concretion analysis in which only exterior 
concretion is available for analysis (and therefore corrosion is estimated using only exterior concretion, see below), we halved the directly measured corrosion rate for the shallow coupons that had corroded extensively on both sides.

Because of the intrusive nature of the directmeasurement technique, it is impractical and undesirable to remove coupons at multiple locations around Arizona's hull. The eight coupons removed in 2002 allowed us directly to measure corrosion rate in eight representative locations, and became control sites for applying less intrusive methods of measuring hull thickness and corrosion rate. We are currently pursuing two simultaneous lines of inquiry: ultrasonic thickness measurements, and estimating corrosion rate by analysing concretion characteristics.

\section{Ultrasonic thickness measurements}

We are working with private-sector companies to use ultrasonic thickness (UT) technology to measure steel thickness, which would then allow us to calculate corrosion rate using equation [3]. Although UT techniques look promising, it requires removal of the concretion and significant surface preparation of the steel hull (buffing and grinding to make the surface as smooth as
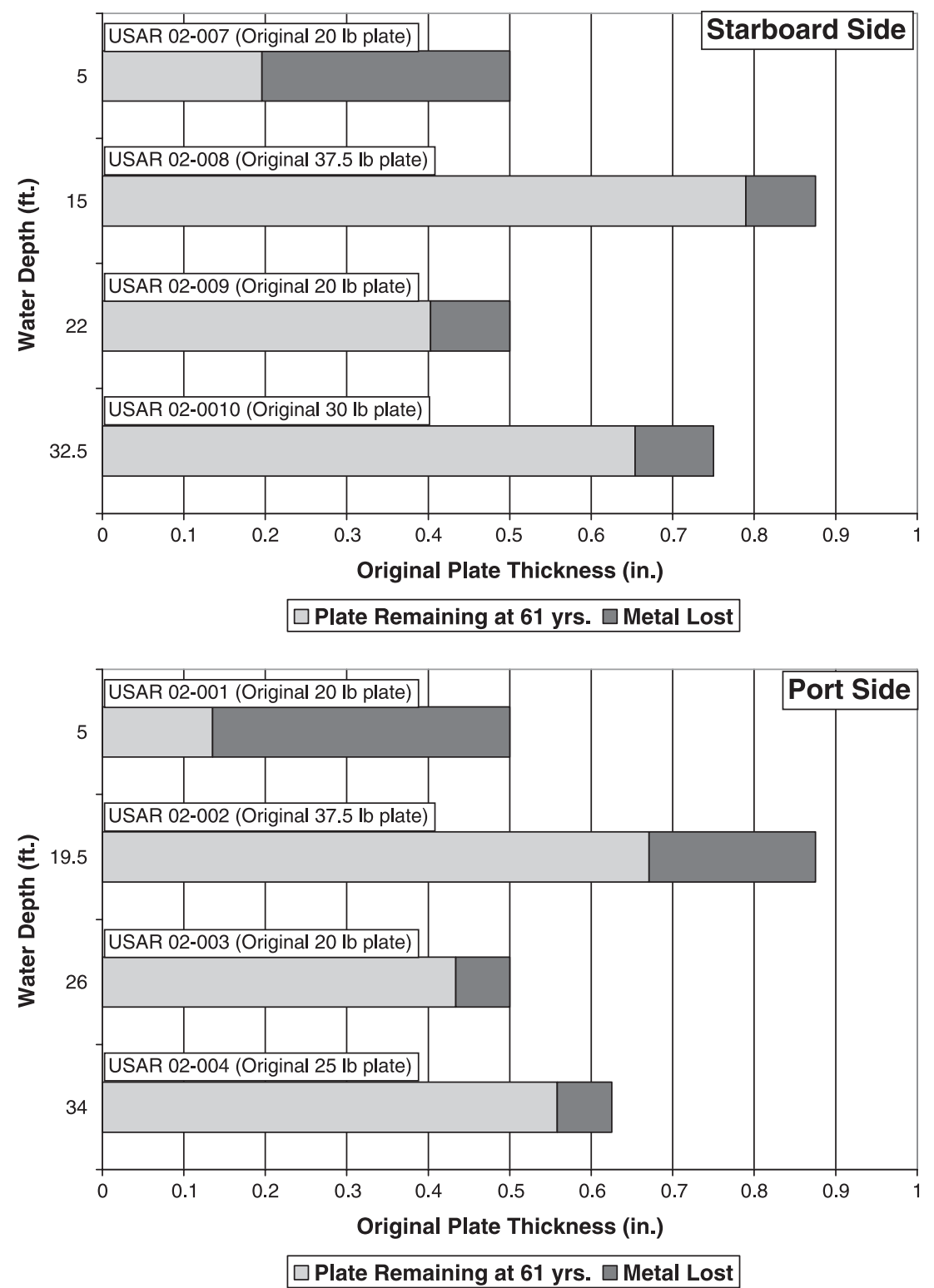

Figure 4. Metal loss as a function of original hull plate thickness and water depth, data from 2002 hull coupons. 


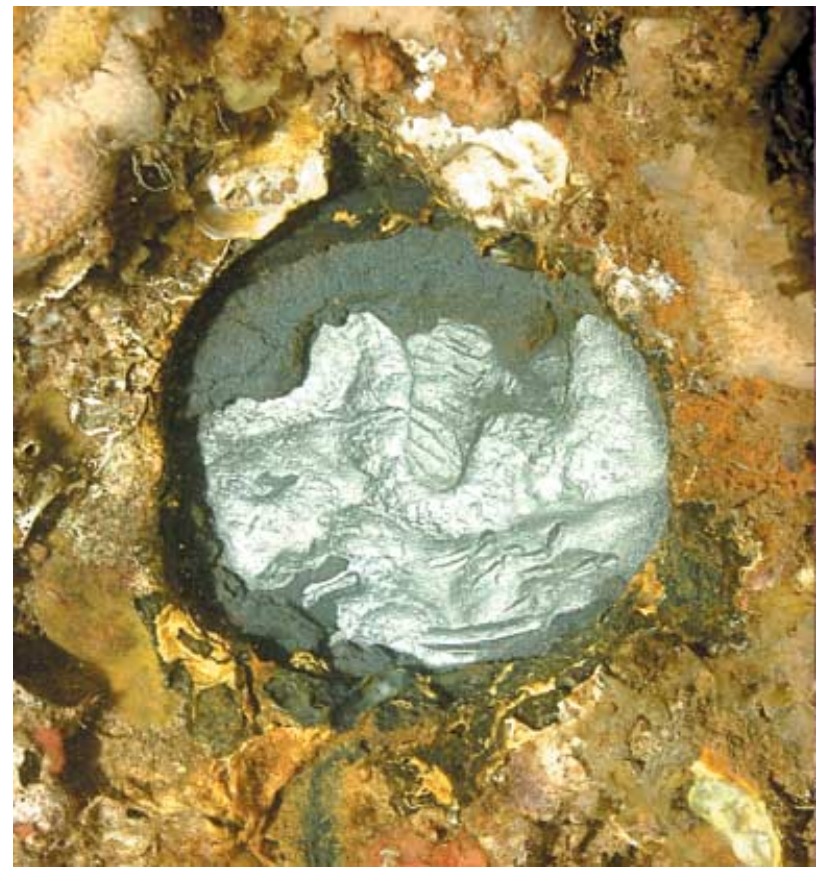

Figure 5. Surface of Arizona's hull after removal of a 76-mm (3-inch) diameter concretion disk and surface preparation. Note the unevenness of the surface, even after significant surface preparation. (Brett Seymour/NPS)

possible) before consistent, repeatable readings can be obtained. In some cases, even after extensive surface preparation, there are locations where UT measurements are unreliable because of unevenness of the surface due to corrosion (Fig. 5), which makes it impossible to couple the face of the UT probe evenly against the hull. Therefore, we are currently focusing our attention on determining corrosion rate by analysing chemical and physical properties of hull concretion.

\section{Corrosion rate determined from concretion}

External hull concretion analysis and its relationship to corrosion on USS Arizona began in the late 1980s. Henderson (1989) observed that hard biofouling layer (concretion) interactions with Arizona's hull may have long-term implications for the battleship's corrosion. Samples of concretion were scraped from the hull, dried, weighed and magnetic corrosion products separated by a bar magnet. In 1998, Johnson et al. (2003) converted the data generated by Henderson (1989) to corrosion rate in mils/yr to illustrate that analysis of the concretion may have merit as a way to determine corrosion rate. Based on these observations, we initiated x-ray diffraction (XRD) and environmental scanning electron microscopy (ESEM) studies on USS Arizona concretion in 1999 at UNL to understand better how the metal hull and the concretion interact. Subsequently, x-ray studies were continued at Eglin Air Force Base, Florida and the University of Florida. Using XRD data, De Angelis (2002) identified the iron minerals siderite $\left(\mathrm{FeCO}_{3}\right)$, with lower residuals of aragonite $\left(\mathrm{CaCO}_{3}\right)$ and magnetite $\left(\mathrm{Fe}_{3} \mathrm{O}_{4}\right)$, as the primary constituents in the concretion (Johnson et al., 2003: 91-2). Measuring distribution of iron in the concretion cross-section using ESEM and $\mathrm{x}$-ray fluorescence (XRF) revealed an estimated total iron content of the concretion between $40 \%$ and $50 \%$ by weight (Johnson et al., 2003: 96-7).

Concretion samples for the current study were obtained in 2003 and 2004 by using a 76-mm (3-in) hole saw bit with a pneumatic drill. After concretion samples were removed, each location

Table 1. Results of hull coupon analysis from 2002

\begin{tabular}{|c|c|c|c|c|c|c|c|c|}
\hline \multirow[b]{2}{*}{ Sample } & \multicolumn{2}{|c|}{ Original Thickness } & \multicolumn{2}{|c|}{ Average Thickness (2002) } & \multicolumn{2}{|c|}{ Water Depth } & \multicolumn{2}{|c|}{$\mathrm{i}_{\text {corr }}$} \\
\hline & in & $\mathrm{mm}$ & in & $\mathrm{mm}$ & $\mathrm{ft}$ & $\mathrm{m}$ & mils/yr & $\mu \mathrm{m} / \mathrm{yr}$ \\
\hline USAR-02-001 & 0.500 & 12.70 & 0.135 & 3.43 & 5.00 & 1.52 & $2.99 *$ & $75.98 *$ \\
\hline USAR-02-002 & 0.875 & 22.20 & 0.671 & 17.04 & 19.50 & 5.94 & 3.34 & 84.59 \\
\hline USAR-02-003 & 0.500 & 12.70 & 0.434 & 11.02 & 26.00 & 7.92 & 1.08 & 27.54 \\
\hline USAR-02-004 & 0.625 & 15.90 & 0.558 & 14.17 & 34.00 & 10.36 & 1.10 & 28.36 \\
\hline USAR-02-007 & 0.500 & 12.70 & 0.196 & 4.97 & 5.00 & 1.52 & $2.49 *$ & $63.36^{*}$ \\
\hline USAR-02-008 & 0.875 & 22.20 & 0.790 & 20.07 & 15.00 & 4.57 & 1.39 & 34.92 \\
\hline USAR-02-009 & 0.500 & 12.70 & 0.403 & 10.24 & 22.00 & 6.71 & 1.59 & 40.33 \\
\hline USAR-02-010 & 0.750 & 19.05 & 0.654 & 16.61 & 32.50 & 9.91 & 1.57 & 40.00 \\
\hline
\end{tabular}

*values halved 


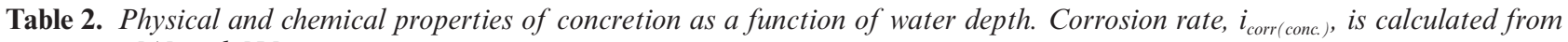
equations [4] and [5]

\begin{tabular}{|c|c|c|c|c|c|c|c|}
\hline \multirow[b]{2}{*}{ Sample } & \multirow{2}{*}{$\begin{array}{l}\text { Thickness } \\
\mathrm{cm}\end{array}$} & \multirow{2}{*}{$\begin{array}{l}\text { Density* } \\
\mathrm{g} / \mathrm{cm}^{3}\end{array}$} & \multirow{2}{*}{$\frac{\text { Total Iron** }}{\% \mathrm{Fe}}$} & \multicolumn{2}{|c|}{ Water Depth } & \multicolumn{2}{|c|}{$\mathrm{i}_{\text {corr(conc) }}$} \\
\hline & & & & $\mathrm{ft}$ & $\mathrm{m}$ & mils/yr & $\mu \mathrm{m} / \mathrm{yr}$ \\
\hline USAR-02-005 & 0.51 & 2.26 & 22.20 & 34.00 & 10.36 & 0.21 & 5.33 \\
\hline USAR-02-006a & 1.15 & 2.25 & 26.00 & 34.00 & 10.36 & 0.55 & 14.01 \\
\hline USAR-02-006b & 0.95 & 2.41 & 45.20 & 34.00 & 10.36 & 0.85 & 21.50 \\
\hline USAR-03-001 & 2.50 & 2.53 & 42.78 & 5.00 & 1.52 & 2.18 & 55.40 \\
\hline USAR-03-002 & 1.20 & 2.34 & 33.86 & 19.50 & 5.94 & 0.77 & 19.48 \\
\hline USAR-03-003 & 1.00 & 1.92 & 21.83 & 26.00 & 7.92 & 0.34 & 8.59 \\
\hline USAR-03-008 & 1.80 & 2.44 & 29.15 & 15.00 & 4.57 & 1.03 & 26.22 \\
\hline USAR-04-002 & 2.10 & 2.43 & 42.09 & 19.50 & 5.94 & 1.70 & 43.30 \\
\hline USAR-04-003 & 1.89 & 2.39 & 46.95 & 26.00 & 7.92 & 1.68 & 42.75 \\
\hline USAR-04-005 & 1.82 & 2.30 & 29.88 & 5.00 & 1.52 & 0.99 & 25.21 \\
\hline USAR-04-006 & 1.84 & 2.55 & 43.77 & 19.50 & 5.94 & 1.63 & 41.40 \\
\hline USAR-04-007 & 1.39 & 2.29 & 41.23 & 26.00 & 7.92 & 1.04 & 26.46 \\
\hline USAR-04-008 & 2.36 & 2.41 & 45.86 & 5.00 & 1.52 & 2.07 & 52.58 \\
\hline USAR-04-009 & 1.95 & 2.47 & 48.16 & 15.00 & 4.57 & 1.84 & 46.76 \\
\hline USAR-04-010 & 1.34 & 2.47 & 34.75 & 22.00 & 6.71 & 0.91 & 23.19 \\
\hline USAR-04-011 & 2.19 & 2.34 & 46.69 & 15.00 & 4.57 & 1.90 & 48.23 \\
\hline USAR-04-012 & 1.71 & 2.43 & 34.25 & 22.00 & 6.71 & 1.13 & 28.69 \\
\hline
\end{tabular}

*Density measurements were made in accordance with ASTM D792-00

**Dry basis

was sealed with a $\mathrm{pH}$-neutral marine epoxyothers have recommended hydraulic cement (see Mardikian, 2004: 147). Data from Arizona concretion analysis reveals that the specific weight of the concretion per unit area (density $\times$ thickness) and total iron in concretion in weight percent $(\% \mathrm{Fe})$ decreases with water-depth. Concurrently, corrosion rate, based on direct-measurement analysis of hull coupons, shows a similar trendcorrosion rate decreases with water-depth (see Fig. 4 and Table 1). While the specific parameters and phenomena that explain these observations are beyond the scope of this paper, the fact that specific weight and total iron content of the concretion show a trend consistent with the direct-measurement data obtained in 2002 has led to further experimentation to correlate concretion properties with corrosion rate.

Due to the complexity and time required to conduct ESEM analysis, we decided to examine direct chemistry as a means of determining total iron content of concretion samples. Carr (2005) developed a standardized method for chemically analysing iron in concretion, and UNL scientists and NPS researchers have combined concretion thickness, density and total elemental iron content to derive an expression for corrosion rate. The applicability of the expression has been confirmed by comparing corrosion rate derived through analysis of concretion properties to corrosion rate obtained by the direct-measurement technique.

\section{Data analysis}

Equation [4] (pers. comm. D. L. Johnson, 2005) expresses corrosion rate determined from physical and chemical properties of the

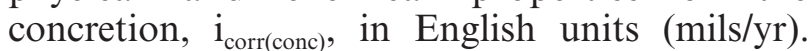
This equation is based on experimental evidence showing that oxygen and iron ion transport through concretion control the corrosion rate. Because density measurements were made in accordance with the American Society for Testing and Material (ASTM) International Standard Test Method for Density and Specific Gravity (ASTM D792-00), which expresses density as grams per cubic centimetre $\left(\mathrm{gr} / \mathrm{cm}^{3}\right)$, concretion thickness must also be expressed in centimetres $(\mathrm{cm})$ :

$$
\mathrm{i}_{\text {corr (conc) }}=\frac{(0.5)(\% \mathrm{Fe})(\mathrm{p})(\mathrm{d})}{\mathrm{t}}
$$

where

$\% \mathrm{Fe}$ is weight percent iron in concretion (dry basis)

$\mathrm{p}$ is concretion density $\left(\mathrm{gr} / \mathrm{cm}^{3}\right)$ 


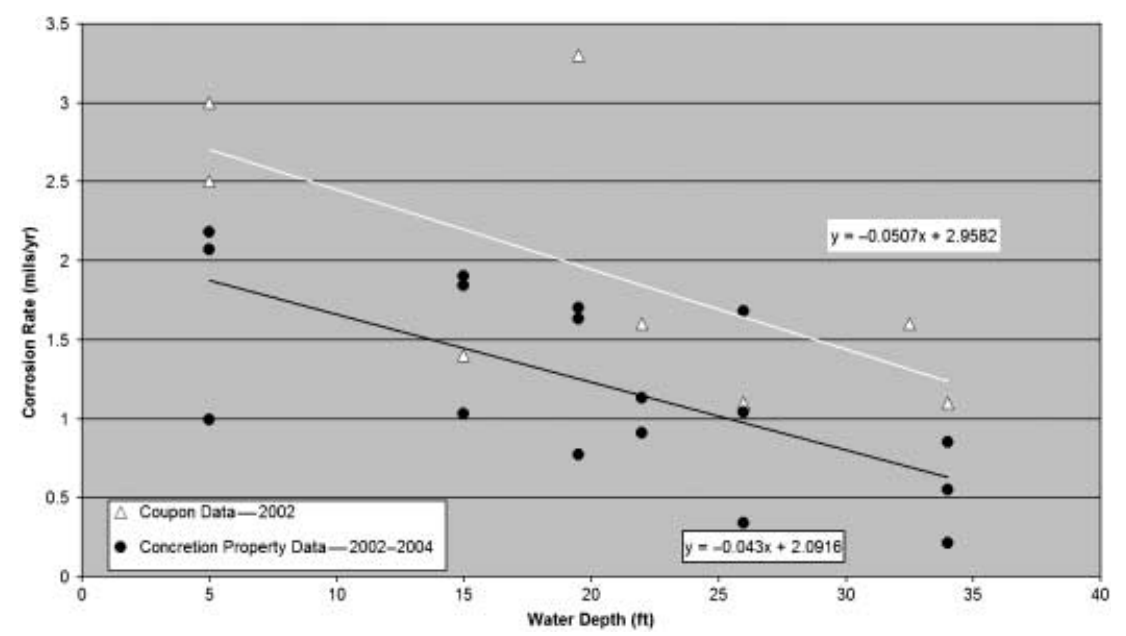

Figure 6. Corrosion rate versus water depth as a function of direct measurement of coupons (white line) and concretion property analysis (black line).

$\mathrm{d}$ is concretion thickness $(\mathrm{cm})$

$\mathrm{t}$ is exposure time in years ( $\mathrm{yr}$ )

0.5 is a unit conversion constant

Using SI units in $\mu \mathrm{m} / \mathrm{yr}$, the equation becomes:

$$
\mathrm{i}_{\text {corr(conc) }}=\frac{(12.7)(\% \mathrm{Fe})(\mathrm{p})(\mathrm{d})}{\mathrm{t}}
$$

where the variables in equation [5] are defined above but with a unit conversion constant of 12.7 .

Physical and chemical properties for 16 concretion samples and corresponding corrosion rates calculated from equations [4] and [5] are tabulated in Table 2. Corrosion rates in mils/yr calculated from concretion constituent analysis (Column 8 in Table 2) and corrosion rates in mils/yr based on the direct-measurement technique (equation [3]) are compared in Fig. 6 and plotted against water-depth in feet. The actual corrosion rate obtained from the directmeasurement technique is higher than that predicted by concretion constituent analysis using equation [4], as indicated by the separation between the two trend lines. The reasons for the difference are: (1) higher initial (pre-concretion) corrosion rates almost certainly produced soluble iron that was not incorporated into concretion; (2) formation of an oxide layer between the steel surface and the concretion, which strongly adheres to the hull and is not captured during concretion removal and therefore is not included in the analysis; and (3) possible interior corrosion. Analysis of the ratios of the two trend lines in Fig. 6 reveals that corrosion rates obtained from the coupons using the directmeasurement technique is higher than corrosion rates predicted by the concretion constituent analysis by a factor of 1.6. With this ratio factored in, a general equation for estimating corrosion rate directly from physical and chemical concretion properties is given in equation [6], where the constants in equations [4] and [5] are multiplied by 1.6 for English and SI units respectively:

$$
\mathrm{i}_{\text {corr }}=\frac{\mathrm{K}(\mathrm{p})(\% \mathrm{Fe})(\mathrm{d})}{\mathrm{t}}
$$

where

$$
\begin{aligned}
& K=0.8 \text { for units in mils } / y r \\
& K=20.32 \text { for units in } \mu \mathrm{m} / \mathrm{yr}
\end{aligned}
$$

Based on the results to date, we believe that concretion constituent analysis may be a viable, minimum-impact method for estimating corrosion rates for steel vessels in seawater.

\section{Recommendations for additional research}

Research to date has focused on correlating corrosion rates obtained from directmeasurement techniques from hull coupons with corrosion rates calculated from physical and chemical concretion properties on USS Arizona's outer hull, from the water surface to just below the mud line, in a water-depth range of 
approximately 1.5 to $10.36 \mathrm{~m}$ ( 5 to $34 \mathrm{ft}$ ). The authors acknowledge these results are based on limited samples and that further testing is required for verification and applicability in other environments. While the present work correlates corrosion rate with water-depth, we believe that depth is probably a characteristic that actually represents numerous other physical and chemical properties more directly determinative of the corrosion process itself. Accurate application of principles used in deriving equation [6] to other sites in marine locations, including those sites located in deep water, will probably require modification after direct correlation with other known corrosion parameters, such as dissolved oxygen concentration, $\mathrm{pH}$, temperature, the ratio of oxygen concentration to concretion thickness, and oxygen and iron mobility through the concretion. In the meantime, however, estimating corrosion rate for steel-hulled vessels in marine environments by analysing physical and chemical concretion properties presents a valid, minimumimpact methodology that only requires removal of a small section of marine encrustation from the vessel under study.

\section{Acknowledgements}

The USS Arizona Preservation Project is funded by the Department of Defense, Legacy Resource Management Fund; National Park Service, Systemwide Archaeological Inventory Program; National Park Service Submerged Resources Center; USS Arizona Memorial; and Arizona Memorial Museum Association. The authors would like to thank John Makinson (Rail Sciences, Inc.); Robert De Angelis (Eglin AFB); Li Ma (NIST); US Navy Mobile Diving and Salvage Unit One; Inspection Technologies, Inc.; Titan Maritime Industries, Inc.; and especially USAR Superintendent Doug Lentz for his continuing support. This manuscript was generously reviewed by Ron Latanision, Tim Foecke, Mike McCarthy, Ian MacLeod, Steve Shope, Paul Mardikian and an anonymous reviewer, all of whose comments greatly improved the presentation of this analysis. It is dedicated to the memory of William N. Weins, who contributed much to USS Arizona corrosion research.

\section{References}

Carr, J. D., 2005, Concretion Analysis for Iron and Calcium. Report submitted to National Park Service Submerged Resources Center, University of Nebraska-Lincoln.

De Angelis, R., 2002, X-Ray Diffraction and Environmental Scanning Electron Microscope Investigation of Concretion from the USS Arizona. Report submitted to National Park Service, Submerged Resources Center, Eglin Air Force Base, Florida.

Gregory, D., 1999, Monitoring the effect of sacrificial anodes on the large iron artefacts on the Duart Point wreck, 1997, IJNA 28.2, 164-73.

Henderson, S., 1989, Biofouling and Corrosion Study, in D. L. Lenihan (ed.), Submerged Cultural Resources Study: USS Arizona Memorial and Pearl Harbor National Historic Landmark. Santa Fe, NM.

Johnson, D. L., Weins, W. N., and Makinson, J. D., 2000, Metallographic Studies of the U.S.S. Arizona, in W. N. Weins (ed.), Microstructural Science Vol. 27: Understanding Processing, Structure, Property, and Behavior Correlations, 85-91. New York.

Johnson, D. L., Makinson, J. D., De Angelis, R., Wilson, B., and Weins, W. N., 2003, Metallurgical and Corrosion Study of Battleship USS Arizona, USS Arizona Memorial, Pearl Harbor. Santa Fe, NM.

Lenihan, D. J. (ed.), 1989, Submerged Cultural Resources Study: USS Arizona Memorial and Pearl Harbor National Historic Landmark. Santa Fe, NM.

McCarthy, M., 1988, SS. Xantho: The pre-disturbance, assessment, excavation and management of an iron steam shipwreck off the coast of Western Australia, IJNA 17.4, 339-47.

MacLeod, I. D., 1987, Conservation of corroded iron artifacts - new methods for on-site preservation and cryogenic deconcreting, IJNA 16.1, 49-56.

MacLeod, I. D., 1995, In situ corrosion studies on the Duart Point wreck, 1994, IJNA 24.1, 53-9.

Makinson, J. D., Johnson, D. L., Russell, M. A., Conlin, D. L., and Murphy, L. E., 2002, In Situ Corrosion Studies on the Battleship USS Arizona, Materials Performance 41.10, 56-60.

Mardikian, P., 2004, Conservation and Management Strategies Applied to Post-Recovery Analysis of the American Civil War Submarine H. L. Hunley (1864), IJNA 33.1, 137-48.

Murphy, L. E. and Russell, M. A., 1997, Minimum Impact Archeology, in J. P. Delgado (ed.), British Museum Encyclopaedia of Underwater and Maritime Archaeology, 278-9. London.

Russell, M. A. and Murphy, L. E., 2003, Long-Term Management Strategies for the USS Arizona: A Submerged Cultural Resource in Pearl Harbor, Hawaii. Legacy Resource Management Fund Project No. 02-170: 2002 Annual Report, Submerged Resources Center Technical Report No. 14. Santa Fe, NM.

Russell, M. A. and Murphy, L. E., 2004, Long-Term Management Strategies for the USS Arizona: A Submerged Cultural Resource in Pearl Harbor, Hawaii. Legacy Resource Management Fund Project No. 03-170: 2003 Annual Report, Submerged Resources Center Technical Report No. 15. Santa Fe, NM.

Russell, M. A., Murphy, L. E., Johnson, D. L., Foecke, T. J., Morris, P. J., and Mitchell, R., 2004, Science for Stewardship: Multidisciplinary Research on USS Arizona, Marine Technology Society Journal 38.3, 54-63. 